\title{
Environment and biogeography of the western boreal forest
}

\author{
by Jim Pojar ${ }^{1}$
}

\begin{abstract}
The western boreal forest of North America (Manitoba through Alaska) has a typical boreal climate, but the largely sedimentary Interior Plains and the northern Cordillera (part of which was ice-free in the Pleistocene) are physiographically and geologically very different from the Canadian Shield that underlies most of the eastern boreal forest. The mountainous nature of much of the region, with pronounced topography, local climates, aspect differences, sharp drainage, and elevational clines, gives some of its boreal landscapes a different character from those of the Shield. The region's forests are structurally consistent with boreal forests everywhere, but floristic differences are apparent, with the loss of eastern species and the addition of Cordilleran and Beringian elements. The southern margins of the western boreal forest also have a distinctive character, as they merge with either the Cordilleran subalpine forests or with aspen parkland and grassland-not with Great Lakes-St. Lawrence conifer-hardwood forests.
\end{abstract}

Several different biogeographic or ecological land classifications have been applied to the western boreal forest. Although there are a variety of classifications, several common themes are apparent. Broad-scale zonation reflects 1) latitudinal change (boreal forest to subarctic woodland to forest-tundra ecotone, from south to north), 2) physiography and biogeography (Plains/Shield to northern Cordillera to Alaska-Beringia, from east to west), and 3) the physiographic vs. vegetation bias of the classification. Regardless of higher-level, broad-scale differences, the various classifications tend to be consistent at the site level, and therefore all have some value and utility for foresters.

\section{Introduction}

The boreal zone or biome is a circumpolar belt that, in places in North America, spans $10^{\circ}$ of latitude. This northern, largely coniferous forest zone is also commonly called the "taiga". "Taiga is a Russian word that appears to have been used originally for the broad ecotone between tundra and subarctic forest in Eurasia. Its use has gradually been extended to include subarctic forests in both Eurasia and North America..." (Daubenmire 1978). Although technically the term boreal forest should perhaps be limited to the closed forest formation (Fig. 1), in practice it usually also includes the subarctic and sometimes subalpine lichen woodland and forest-tundra ecotone formations (Elliott-Fisk 1988).

The boreal forest is the most extensive vegetation formation or biome type in North America, covering nearly $30 \%$ of the landmass of North America north of Mexico (Barbour and Christensen 1993). In the recent past, the dominant cultures

\footnotetext{
'Forest Science Officer, British Columbia Forest Service, Prince Rupert Forest
} Region, Postal Bag 5000, Smithers, British Columbia, Canada V0J 2 NO.
La forêt boréale occidentale de l'Amérique du Nord (du Manitoba à l'Alaska) connaît un climat boréal typique, mais les Plaines de l'intérieur principalement sédimentaires et la Cordillère nordique (dont une partie n'a pas été recouverte de glace au cours du Pléistocène) sont physiographiquement et géologiquement très différentes du Bouclier canadien où l'on retrouve la plus grande partie de la forêt boréale orientale. La nature montagneuse pour la majeure partie de la région, avec sa topographie accentuée, ses climats locaux, ses différents aspects, son drainage rapide et ses clines d'élévation, a engendré pour certains de ces paysages boréaux un caractère différent de ceux du Bouclier. Les forêts de la Region sont structuralement semblables aux forêts boréales du monde, mais des différences floristiques sont apparentes, par suite de la perte des espèces orientales et l'apport des éléments de la Cordillère et de la région de Bering. Les limites australes de la forêt boréale occidentale ont également un caractère distinctif, puisqu'elles se marient avec les forêts subalpines de la Cordillère ou avec les boisés de peupliers ou les prairies, mais non avec les forêts de feuillus et de conifères de la région des Grands-Lacs et du St-Laurent.

Plusieurs classifications biogéographiques ou écologiques différentes ont été appliquées à la forêt boréale occidentale. Mêmes s'il existe plusieurs classifications, certains thèmes demeurent communs. Le découpage en zone selon une échelle assez étendue reflète: 1) le changement en fonction de la latitude (de la forêt boréale à la forêt clairsemée subarctique à l'écotone forêt-toundra, en progressant du sud vers le nord); 2) la physiographie et la biogéographie (des Plaines/Bouclier vers la Cordillière nordique vers l'Alaska et la région de Béring, en progressant de l'est vers l'ouest); et 3) le biais physiographique par opposition au biais végétatif de la classification. En dépit des différences retrouvées à un niveau supérieur et selon une échelle assez étendue, les différentes classifications tendent à être uniformes au niveau de la station, et ainsi ont toutes une certaine valeur et une certaine utilité pour les forestiers. in North America have largely dismissed the taiga as a vast, uniform, resource-poor, biologically depauperate, unforgiving hinterland. In the last few decades, the boreal forest has been the scene of exploration and exploitation of mineral, petroleum, hydroelectric, and forest resources, and has come to be viewed as a very complex and dynamic system that plays a key role in atmospheric processes and in global climate and element budgets (Bonan and Shugart 1989). The accelerated resource development and the hints of Gaia-style forest-environment interactions have prompted much study of the structure and function of boreal forests and of the environmental factors that control the ecosystem patterns.

\section{Western Boreal Forest}

The western boreal forest extends from Manitoba west through Alaska, from elevations near sea level to (in the northern Rocky Mountains) about $1000 \mathrm{~m}$. The boundary between western and eastern regions is somewhat arbitrary. Physiographically, the line between the Interior Plains and the great Canadian Shield cuts through southern Manitoba (along Lake Winnipeg) and diagonally across northern Saskatchewan 


\section{Boreal Forest Formations}

Forest-Tundra

Lichen Woodland

Closed Forest

$5001000 \mathrm{~km}$

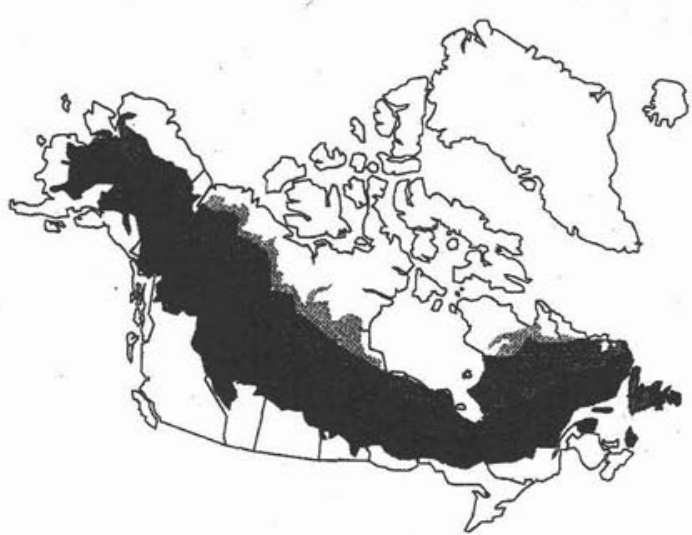

Fig. 1. The boreal forest of North America, divided into three formations: closed forest, lichen woodland, and forest-tundra ecotone [adapted from Elliott-Fisk (1988)]. and Northwest Territories. Climatically and biologically, there is a more eastern boundary between subhumid and moist climatic regimes, that runs north from Rainy River-Dryden, Ontario (and presumably northern Minnesota) north to Hudson Bay (Ecoregions Working Group 1989). In western Canada, the boreal forest meets the mountains, and mingles with subalpine forest and scrub in Alberta, northern British Columbia, and Yukon. In Alaska, the boreal forest zone is essentially intermontane, between the Coast, Alaska, and Brooks ranges. To the south, there are transitions to aspen parkland and grassland east of the Rockies (Hogg 1994), and to Great Lakes-St. Lawrence mixed forest to the southeast (Rowe 1972). To the north, there are transitions to Arctic tundra (Elliott-Fisk 1988).

\section{Environment}

The physical environment largely determines the nature and patterns of boreal ecosystems. Climate has imposed an aspect of evergreen needleleaf forest on most of the boreal zone. However, the interplay of surficial deposits, permafrost, surface water, local relief, and slope aspect, on a stage designed by Pleistocene glaciation, and choreographed by wildfire and other disturbances, results in a variety of communities and ecosystems.

\section{Climate}

The regional climate can be classified as cool, humid, microthermal (Hare 1950; Hare and Ritchie 1972). It is a northern, continental $\left(-50^{\circ}\right.$ to $+35^{\circ} \mathrm{C}$ extremes of temperature) climate, with long very cold winters, short relatively cool (but briefly warm and intense) summers, and maximum precipitation in the summer. Broad-scale climatic gradients include: decreasing temperature and net radiation with increasing latitude, decreasing temperature with increasing elevation, and air-mass trajectories (especially the Cordilleran and Arctic airstreams) that reflect longitude and distance from oceans (Brouillet and Whetstone 1993). In the more northern parts of the region, there is a general gradient of decreasing moisture from east to west (from northern Manitoba through northern Alberta, Mackenzie District, Yukon, to central Alaska); the trend is opposite in the southern parts, from the Rocky Mountains east (Hogg 1994). Topoclimatic variations can be very impor- tant in controlling forest existence and distribution, especially in mountainous regions, as manifested by altitudinal timberlines and pronounced aspect differences.

\section{Physiography, Geology, Terrain}

Three broad physiographic regions can be delimited (Fig. 2) in the western boreal forest (Wahrhaftig 1965; Bostock 1970). The eastern Kazan Region is part of the granitic/gneissic Precambrian Shield. The central Interior Plains and the western Cordillera (where true boreal forest is largely intermontane or confined to valley systems) are both underlain primarily by Paleozoic and Cretaceous sedimentary and Metamorphic rock. Most of the region experienced intense Pleistocene glaciation; till and outwash predominate, with lacustrine and fluvial deposits locally important. But a large area in central Alaska and adjacent Yukon was ice-free in the Pleistocene (Fig. 3) (Péwé 1975), and has significant aeolian deposits (loess).

\section{Soils}

Dominant soil orders in the western boreal forest are Brunisols (Inceptisols), Regosols (Entisols; especially in the Cordilleran Region), Gleysols (Entisols and Inceptisols), Organics (Histosols), Cryosols (Pergelic subgroups), Podzols (Spodosols; especially in the Kazan Region), and Luvisols (Alfisols; especially in the Interior Plains).

Key edaphic features include cold soil temperatures, poor drainage, thick insulating feathermoss/lichen/surface organic layers, low available nutrients, and permafrost. Permafrost may be present or absent; much of the western boreal forest is in the zone of discontinuous permafrost (Brown and Péwé 1973). Such conditions result in relatively slow tree growth. Productivity is limited by low temperature (often compounded by high soil moisture), build-up of forest floor biomass, slow rates of decomposition of organic matter by soil microorganisms, acidic soils, low levels of available nitrogen and minerals, and limited nutrient cycling.

However, stand-destroying disturbances can reset the ecological clock, resulting in more productive early- and mid-seral forests, especially in the warmer parts of the region. Disturbanceprone, nutrient-rich sites, such as floodplains, also exhibit much better tree growth than in the prevailing upland forest. 
Fig. 2. Physiographic regions of the western boreal forest [adapted from Bostock (1970)].

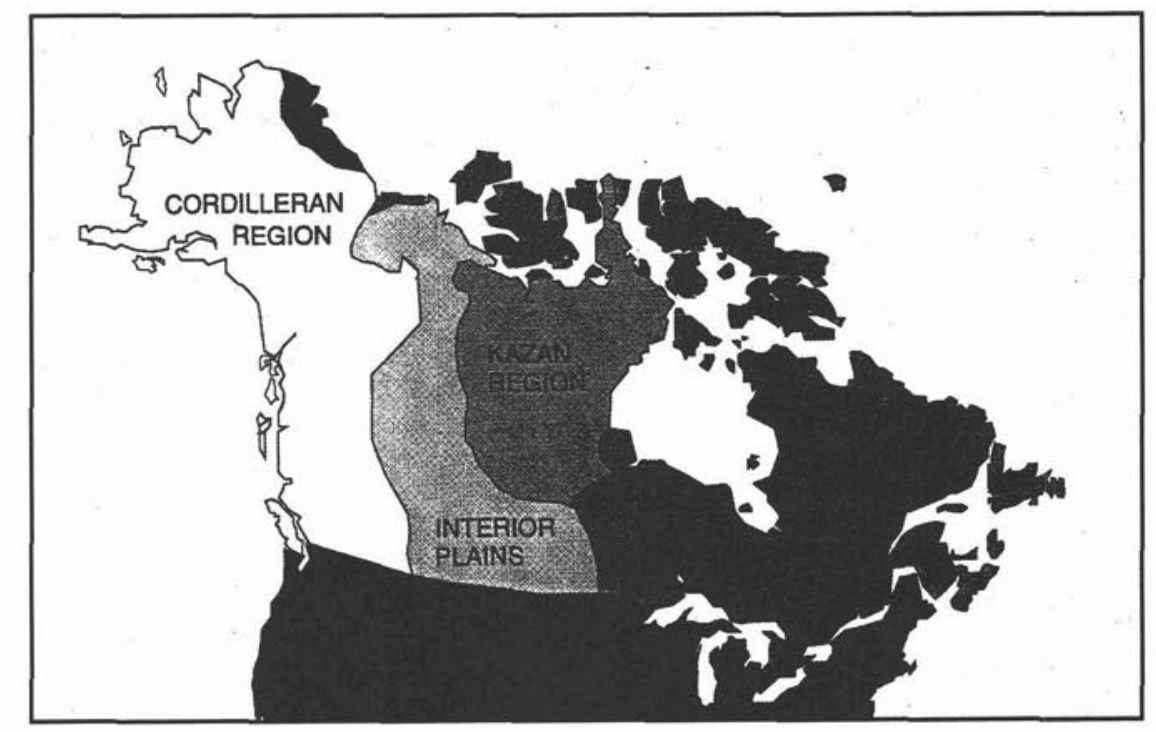

Fig. 3. Extent of Pleistocene glaciation in North America [adapted from Murray (1987)].

\section{Vegetation \\ Forest}

The physiognomy of the prevailing mature vegetation of this enormous region is pretty consistently evergreen needleleaf coniferous forest, but deciduous broadleaf hardwood and mixedwood forests are common and often extensive. Forests predominate in better drained areas. The dominant plants are conifers (species of Picea and Pinus, plus Abies and Larix) and deciduous hardwoods (species of Populus and Betula) (Table 1).

The spruces are white (Picea glauca) and black (P. mari$a n a)$, the two transcontinental species that essentially define the extent of the vast North American taiga. The pines and true firs each consist of a pair of closely related species: jack pine/lodgepole pine (Pinus banksiana/P contorta) and balsam fir/subalpine fir (Abies balsamealA. lasiocarpa). Jack pine and balsam fir are eastern (east of the Rockies), continental species, lodgepole pine and subalpine fir are cordilleran. In Alaska, the boreal forest has no pines and no true firs. Tamarack (Larix laricina) is nearly as widespread as the spruces but patch- ier in distribution, especially in the western, cordilleran part of the region-perhaps because peatlands are also patchy. All three of the major hardwood trees (paper birch, Betula papyrifera; trembling aspen, Populus tremuloides; balsam poplar, $P$. balsamifera) are also widespread transcontinental species.

Although they have huge ranges, all our boreal tree species are confined to North America; similarly, the Eurasian boreal spruces, pines, larches, birches, and poplars are confined to Eurasia. The principle seems to be that plant species of lower strata in the forest are more wide ranging, and the lower the layer the broader the range of its species. Thus, there are no circumboreal trees, a few circumboreal shrubs, many circumboreal herbs, and very many circumboreal bryophytes and lichens (Larsen 1980).

The most dominant shrubs of the western boreal forest are willows (Salix spp.) and members of the heather family (Ericaceae). The willows for the most part dominate in open forest or non-forested habitats, whereas the heather-family shrubs are characteristic of the closed forest ground cover and are also abundant in open habitats. The ericaceous shrubs seem to thrive 


\begin{tabular}{|c|c|c|}
\hline \multicolumn{3}{|l|}{ Conifers } \\
\hline Picea & Spruce & glauca, mariana \\
\hline Abies & Fir & balsamea/lasiocarpa \\
\hline Pinus & Pine & banksiana/contorta \\
\hline Larix & Tamarack & laricina \\
\hline \multicolumn{3}{|c|}{ Hardwoods } \\
\hline Populus & Poplar & balsamifera, tremuloides \\
\hline Betula & Birch & papyrifera \\
\hline Alnus & Alder & crispa, tenuifolia \\
\hline Salix & Willow & spp. \\
\hline
\end{tabular}

in the thick, moist, cold and acidic organic layers that cover the soil surface of many of the region's ecosystems. There is also evidence that some ericaceous shrubs and their mycorrhizal endophytes can absorb organic nitrogen compounds such as amino acids and polypeptides, thus enhancing their adaptedness to soils poor in inorganic nitrogen (Read 1991; Kielland 1994).

The ground cover of upland boreal forest is fairly consistent, at least in terms of dominant species composition. Floristic and vegetation discontinuities do occur along landscape transitions; for example, north of Great Slave Lake, between basic loamy Cryosols underlain by sedimentary rock to the northwest and coarse-textured acidic Brunisols on the Shield to the southeast (Timoney et al. 1993). However, species generally shift in relative abundance more so than in presence/absence. The herb layer typically consists mostly of circumboreal (e.g. Linnaea borealis, Pyrola secunda, Lycopodium annotinum, Equisetum sylvaticum, Goodyera repens) and transcontinental species (e.g. Cornus canadensis, Geocaulon lividum, Viola renifolia), with a few (in the western boreal forest) additional cordilleran/amphiberingian (e.g. Lupinus arcticus, Aconitum delphinifolium) and eastern species (e.g. Rubus pubescens, Maianthemum canadense, Aralia nudicaulis) (La Roi 1967).

Moss cover in the forest is primarily Pleurozium schreberi and Hylocomium splendens, the ubiquitous circumboreal feathermosses, as well as species of Sphagnum, Dicranum, and Polytrichum, among others (La Roi and Stringer 1976). The thick moss-organic layer on the forest floor is a key structural and functional component of boreal forest, controlling energy flow, nutrient cycling, water relations, and stand productivity and dynamics (Bonan and Shugart 1989).

Lichens can also be a conspicuous component of the boreal forest floor, often forming the dominant ground cover in open spruce or pine forests - most characteristically in the transition region between boreal forest and tundra.

\section{Other vegetation types}

Besides closed forest, boreal plant cover includes woodland, deciduous scrub, localized scrub-steppe, and myriad wetlands.

\section{Woodland}

Physiognomically there are many types of open forest or woodland, i.e. scattered trees, canopy coverage $10-25 \%$ (Fosberg 1967). Perhaps the best known in the boreal zone is the 'lichen woodland' of the northern or subarctic part of the taiga. The northern lichen woodland typically has scattered individuals of white or black spruce and a ground cover of fruticose lichens in the genera Cladonia, Cladina, and Stereocaulon (Kershaw 1977). In the western boreal forest, lichen woodland can also occur at higher elevations, approaching the altitudinal timberline, and on dry, coarse-textured, nutrient-poor sites virtually anywhere within the matrix of closed forest. These altitudinal and edaphic lichen woodlands can have pines and subalpine fir as well as the spruces. Woodland with a dominant understory of deciduous shrubs (species of Salix and Betula glandulosa) is actually more widespread in the western boreal forest than is lichen woodland.

\section{Scrub}

Scrub or shrublands are common throughout the taiga, especially at higher latitudes and elevations. The dominant species are low to tall $(0.5-5 \mathrm{~m})$ deciduous shrubs, dozens of species of Salix (but especially S. glauca, S. planifolia, S. arbusculoides, $S$. barclayi, S. alaxensis, S. bebbiana, S. scouleriana, S. interior in the western boreal forest) plus Alnus crispa (green alder) and Betula glandulosa (dwarf birch).

\section{Scrub-steppe}

Grassland and scrub-steppe communities typically occur on dry, often south-facing slopes above many of the major rivers of the region (Raup 1934; Moss 1952; Pojar 1983). Such habitats usually cover small areas, but they can be more extensive in drier, warmer parts of the region. Typical shrubby species include wild roses (Rosa), saskatoon (Amelanchier alnifolia), and stunted aspen. Species of sage (Artemisia), wheatgrasses (Agropyron), fescues (Festuca), and purple reedgrass (Calamagrostis purpurascens) characterize the herb layer (Moss 1952; Douglas 1974; Pojar 1983; Viereck et al. 1992).

\section{Wetlands}

Wetlands, especially peatlands, are a major feature of the boreal landscape. Ombrotrophic bogs - peatlands that receive nutrients only from the atmosphere - are the most common and widespread type of wetland. These bogs are physiognomically uniform throughout the boreal zone, being dominated by a matrix of Sphagnum and a diverse group of ericaceous shrubs (Larsen 1982). Many of the shrubs are evergreen xeromorphs because of the short growing season, fluctuating water table, and the nutrient-deficient rooting medium (Elliott-Fisk 1988). Stunted black spruce and tamarack are the most common tree species in the bogs. Fens are peatlands that are less acidic and richer in nutrients than bogs, and have less Sphagnum and ericaceous shrubs and more willows, dwarf birch, sedges, and grasses. Fens are also common and diverse in the western boreal region (Zoltai et al. 1988), with some wonderful examples of ribbed or patterned fens in the northern prairie provinces. More elaborate classifications of the impressive variety of peatlands, based on topography, hydrology, water chemistry, and landscape evolution, have been devised by Heinselman (1963, 1970), Larsen (1982), and Zoltai et al. (1988), among others.

\section{Ecosystem Dynamics}

The model of ecosystem dynamics developed by researchers in Alaska (Van Cleve et al. 1983, 1986, 1991) seems to apply generally to the western boreal forest, or at least to its central, coniferous forest core. Uplands are dominated by evergreen conifers, which retain their foliage for several years and tend to be nutrient-conservative, and are adapted to nutrient- 


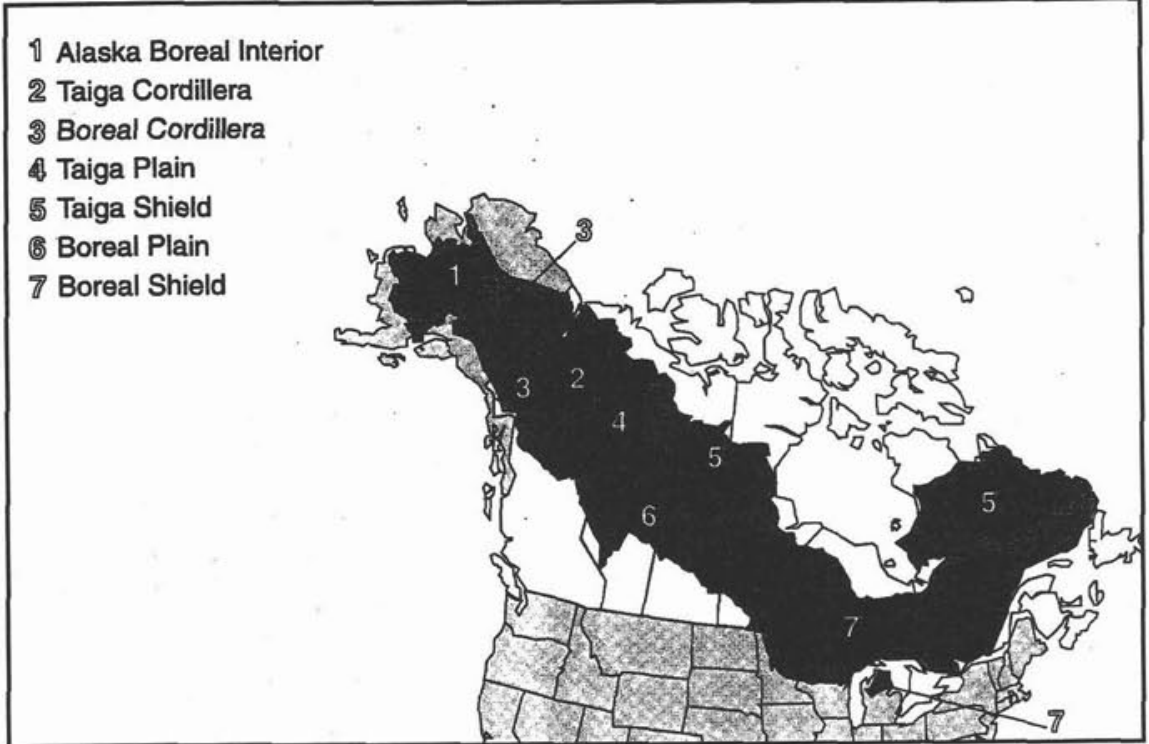

Fig. 4. North American ecological areas with boreal forests [adapted from manuscript map, U.S. Environmental Protection Agency/ Environment Canada (1994)]. poor conditions. The thickness of the surface organic layer increases with time during succession in these upland forests, organic material is stored in a largely undecomposed state on the forest floor, and nutrients are held largely in the surface organic and mineral A horizons. Decomposition is slow because of low temperatures, resulting in increased insulation of the soil, yet lower soil temperatures, decreased active-layer thickness (if permafrost is present), and impeded drainage. So with time and succession, the surface organic layer thickens, soil temperature decreases, soil moisture increases, soil nutrient availability decreases, and net primary productivity declines — even though forest biomass may continue to slowly increase. Of course, different pathways occur on different site types: floodplains, warm south slopes, bogs.

Disturbance counteracts these trends. Stand-destroying wildfires are frequent, sufficiently so that succession of the initial cohort by a new generation of trees often does not occur (Dix and Swan 1971). Most wildfires are less than 5 ha in extent (Rowe and Scotter 1973), but in severe years individual fires can cover 50,000 ha or more. Most of the burned area is accounted for by a few large fires in severe fire years (Bonan and Shugart 1989). Wildfire is a key ecosystem process. As Rowe (1961) declared: "The boreal forest is a disturbance forest, usually maintained in youth and health by frequent fires to which all species, with the probable exception of fir, are nicely adapted." Other stand-destroying disturbances include insect outbreaks and windthrow (which often precede fire), and flooding. Very dynamic disturbance regimes and multi-path succession interact with the environmental complex to produce high ecosystem and landscape diversity. Thus, although the boreal forest is species-poor (at least in above-ground organisms) (Shaw et al. 1991), "variations in slope, aspect, drainage, postfire successional stage, and vegetation result in larger changes within shorter distances than occur in humid middle latitude and tropical landscapes" (Van Cleve et al. 1983).

\section{Regional Variation}

Although it presents a relatively uniform aspect throughout a vast area, and has comparatively low species diversity of vascular plants, the boreal forest is not the same everywhere, not even in western North America. Several ecological classification schemes have been applied to the North American boreal forest, in an attempt to sort out the latitudinal and regional variation.

Strictly on the basis of vegetation, the boreal forest can be broadly divided into three structural units or 'formations': closed forest, lichen woodland, and forest-tundra ecotone (Fig. 1) (ElliottFisk 1988). The northern treeline separates the lichen woodland from the forest-tundra ecotone (or sometimes the tundra proper). In another physiognomic approach, Rowe (1972) delimited three boreal "subregions": forest, forest and barren (to the north), forest and grass (to the south).

Other classifications combine physiography with variations in the relative importance of dominant plant species and communities. Larsen (1980) divided (but did not map) the North American boreal forest "zone" into seven "regions", five of which occur in the western boreal forest. The Alaska region (1) is dominated by white spruce and paper birch with minor aspen on upland sites, and by black spruce and minor tamarack on poorly drained sites. The Cordilleran region (2) is influenced by the diverse topography of the mountains of northern British Columbia, Yukon, and southwest Mackenzie District. Here the boreal forest intergrades with and shares many species (such as subalpine fir) with montane and subalpine ecosystems. The Interior region (3) extends from the Cordilleran foothills eastward to the edge of the Canadian Shield. In addition to the spruces, aspen, and balsam poplar, jack pine and lodgepole pine are important tree species; tamarack and balsam fir are less abundant. On the Canadian Shield (region 4), balsam fir becomes increasingly important; black spruce, white spruce, jack pine, and tamarack increase in dominance northwards and black spruce dominates towards the northern treeline. To the south in this region, the forests become richer in species and grade into the conifer-hardwood forests of the Great Lakes area. The fifth region is the Northern Forest Border, which is also called the northern boreal boundary, the continental Arctic treeline, the northern forest-ecotone, and so forth. Here black spruce dominates, but white spruce occurs on well-drained sites and tamarack occurs in wet areas. 


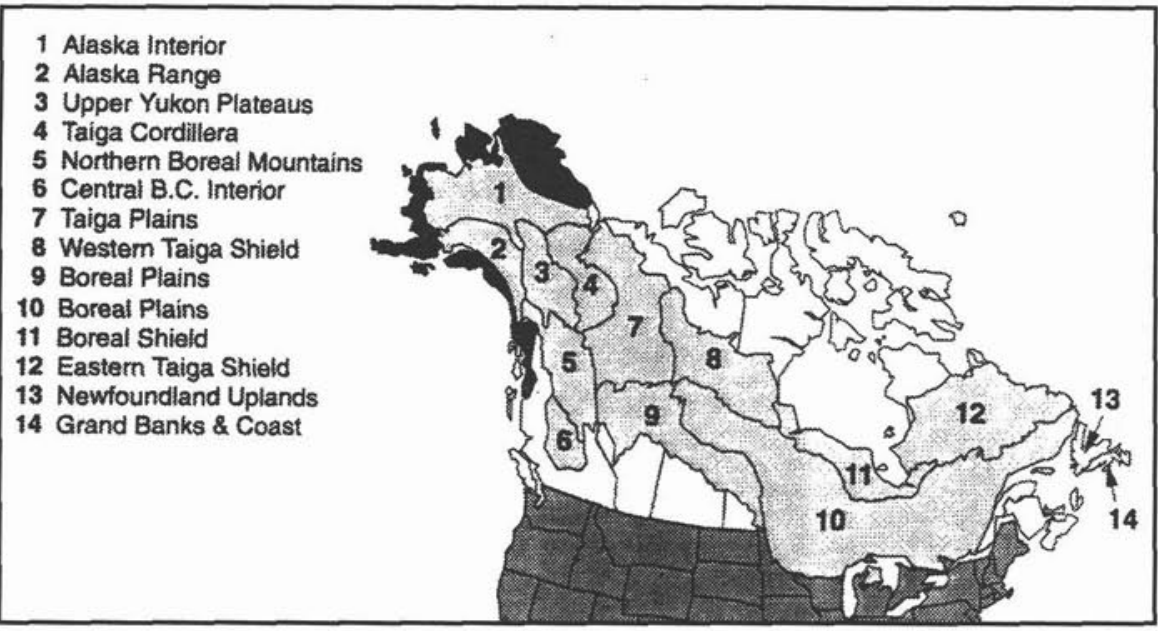

Fig. 5. North American ecoprovinces with boreal forests (adapted from manuscript map by D.A. Demarchi (1994), British Columbia Ministry of Environment, Lands, and Parks, Victoria, BC).

Fig. 6. Forest formations and zones in Alaska [adapted from Zasada and Packee (1994)].

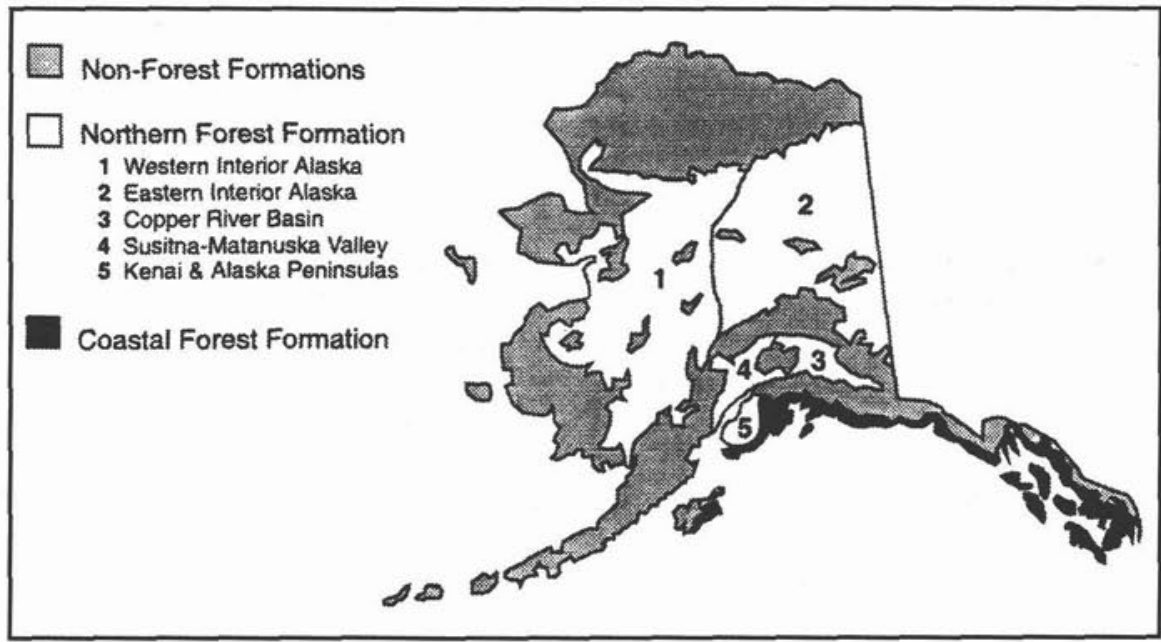

The 'ecological areas' devised jointly by the U.S. Environmental Protection Agency and Environment Canada (Fig. 4) roughly parallel Larsen's forest regions. The western boreal forest has seven of these areas: Alaska Boreal Interior, Boreal Cordillera, Taiga Cordillera, Boreal Plains, Taiga Plains, Boreal Shield, Taiga Shield.

The Canadian Committee on Ecological Land Classification (Ecoregions Working Group 1989) has delimited seven (in western Canada) 'ecoclimatic regions', which attempt to reflect a combination of climate, physiography, and vegetation. Their regions are: Mid- and Northern Cordilleran, Low, Mid-, and High Boreal, Low and High Subarctic. Alaska would probably fit into this scheme as an eighth, western cordilleran region.

Demarchi has recently produced a useful map (Fig. 5) depicting the "ecoprovinces" of North America; there are nine or ten of these ecoprovinces in the western boreal forest. At a lower level in his classification, Rowe (1972) subdivides forest regions into forest sections, based on "distinctive patterns of vegetation and physiography." There are 24 or so sections in the boreal forest region of western Canada.

Several other classifications have been developed for parts of the western boreal forest, but they tend to be of limited scope or at an inappropriate scale for a meaningful "big picture". "Ecoregions" have been described for Alberta (Strong and Leggatt
1981), Yukon (Oswald and Senyk 1977), British Columbia (Demarchi et al. 1990), and Alaska (Bailey 1994; Gallant et al. 1994); they all appear to be conceptually different. British Columbia also has "biogeoclimatic zones" (Pojar et al. 1987; Meidinger and Pojar 1991). Alaska also has mapping of generalized vegetation types (Viereck 1971) and a detailed vegetation classification (Viereck et al. 1992), plus "forest formations and zones" (Fig. 6) (Zasada and Packee 1994) the latter appears to best reflect regional variation.

This welter of classifications and maps can be confusing and irritating to someone trying to develop a grand unified biogeographic view of the boreal forest, especially when most of them are confined to one country, state, or province. But in the end it probably does not matter, at least to foresters. Most ecological land classifications have much in common, most fundamentally the forest site itself, and have many applications in forestry (see the collection of papers on site classification in Forestry Chronicle 68 (1); Feb. 1992 issue). Regardless of nomenclatural and substantive differences, which result from dissonant scales as well as from different approaches, foresters can select the appropriate map, site classification and application from what is available, and can usually figure out what they need to know. Most ecological classifications have greatest utility to operational foresters at the site level rather than the zonal or regional level. Compare the site transect dia- 
grams in Van Cleve et al. (1983), Stanek and Orloci (1987), Meidinger and Pojar (1991), Corns and Annas (1986), Kabzems et al. (1976), Sims et al. 1989), and others from eastern Canada, and you will quickly see that forest ecologists from Alaska to Newfoundland tend to delimit the same kinds of site types on similar landscapes. These site types are what operational foresters use most. In contrast, the zonal level is especially useful for foresters involved in regional planning, state of the environment reporting, protected areas system planning.

\section{Conclusions}

At one, essential level it is all boreal forest, regardless of where you are in the North between prairie and tundra. This vast and regionally diverse biome is unified by several major, pervasive ecological themes: cold, conifers, carbon storage, mosquitoes, fire, and change. The western boreal forest has more environmental factors and biotic elements in common with its eastern counterpart than it has distinctive differences. Yet there are differences, especially west of the Rockies; the Cordilleran and Beringian influences on physiography, glacial history, and floristics are clear.

The variety of zonal or regional classifications reflects the diversity of classifiers and their writs, as much as anything. Nevertheless, several common biogeographical themes are also apparent in the western boreal forest. Broad-scale zonation reflects at least three underlying factors. There is a latitudinal climatic change from south to north, which is straightforwardly dealt with in the sequence boreal forest to subarctic woodland to forest-tundra ecotone, or forest-and-grass to forest to forestand-barren. There are as well at least three major physiographic and biogeographic realms in the western boreal forest: the PlainsShield, the northern Cordillera, and Alaska-Beringia. Furthermore, differences in ecological land units at lower levels (finer scales) tend to reflect the principles and biases of the classification employed. In particular, there are differences between physiographic-based and vegetation-based classifications, and between mapping-regionalization and agglomerative classification (Rowe 1992). These differences are relatively inconsequential for foresters, who should be using both approaches and whatever works.

\section{Acknowledgements}

I thank D. Izard and A. Maclean for preparing the figures. D. Demarchi and I. Marshall helped me track down ecoregion maps of all descriptions. S. Harrison, R. Kabzems, A. MacKinnon, and J. Zasada provided useful comments and information during manuscript preparation. The B.C. Forest Service supported this work.

\section{References}

Bailey, R.G. 1994. The United States ecoregions map. Revised @ 1:7,500,000. U.S.D.A For. Serv., Fort Collins, CO.

Barbour, M.G. and N.L. Christensen. 1993. Vegetation. Pp. 97-131. In: Flora of North America Editorial Committee, eds. Flora of North America north of Mexico. Vol. 1. Introduction. Oxford Univ. Press, New York.

Bonan, G.B. and H.H. Shugart. 1989. Environmental factors and ecological processes in boreal forests. Ann. Rev. Ecol. Syst. 20: 1-28. Bostock, H.S. 1970. Physiographic subdivisions of Canada. Pp. 9-30 In: R.J.W. Douglas, ed. Geology and economic minerals of Canada. Economic Geology Rep. No. 1. 5th ed. Ottawa, ON.

Brouillet, L. and R.D. Whetstone. 1993. Climate and physiogra- phy. Pp. 15-46 In: Flora of North America Editorial Committee, eds. Flora of North America north of Mexico. Vol. 1 Introduction. Oxford Univ. Press, New York.

Brown, R.J.E. and T.L. Péwé. 1973. Distribution of permafrost in North America and its relationship to the environment: a review, 1963-1973. Pp. 71-100 In: Permafrost: Proc. Second Int. Conf. (North Am. Contribution). Nat. Acad. Sci., Washington, DC.

Daubenmire, R. 1978. Plant geography with special reference to North America. Academic Press, New York. 338 p.

Demarchi, D.A., R.D. Marsh, A.P. Harcombe and E.C. Lea. 1990. The environment. Pp. 55-144 In: R.W. Campbell, N.K. Dawe, I. McTaggart-Cowan, J.M. Cooper, G.W. Kaiser and M.C.E. McNall. The birds of British Columbia. Vol. 1. Royal British Columbia Museum and Environment Canada, Canadian Wildlife Service. Victoria, BC.

Dix, R.L. and J.M.A. Swan. 1971. The roles of disturbance and succession in upland forest of Candle Lake, Saskatchewan. Can. J. Bot. 49: 657-676.

Douglas, G.W. 1974. Montane zone vegetation of the Alaska River region, southwestern Yukon. Can. J. Bot. 52: 2505-2532.

Ecoregions Working Group. 1989. Ecoclimatic regions of Canada, first approximation. Canada Committee on Ecol. Land Classification. Ecol. Land Class. Ser. No. 23. Environment Canada, Ottawa, ON. $118 \mathrm{p}$.

Elliott-Fisk, D.L. 1988. The boreal forest. Pp. 33-62 In: M.G. Barbour and W.D. Billings, eds. North American terrestrial vegetation. Cambridge Univ. Press, Cambridge, England.

Fosberg, F.R. 1967. A classification of vegetation for general purposes. Pp. 73-133 In: G.F. Peterken, ed. Guide to the checklist for IBP areas. IBP Handbook No. 4. Blackwell, Oxford, England.

Gallant, A.L., E.F. Binnian, J.M. Omernik and M.B. Shasby. 1994. Ecoregions of Alaska. U.S.G.S. Prof. Pap. xxx. U.S. Geol. Surv., U.S. Environm. Prot. Agency and Colorado State University. (in press). Hare, F.K. 1950. Climate and zonal divisions of the boreal forest formation in eastern Canada. Geogr. Rev. 40: 615-635.

Hare, F.K. and J.C. Ritchie. 1972. The boreal bioclimates. Geogr. Rev. 62: 333-365.

Heinselman, M.L. 1963. Forest sites, bog processes, and peatland types in the glacial Lake Agassiz region, Minnesota. Ecol. Monogr. 33: 327-374.

Heinselman, M.L. 1970. Landscape evolution, peatland types, and the environment in the Lake Agassiz peatlands natural area, Minnesota. Ecol. Monogr. 40: 235-261.

Hogg, E.H. 1994. Climate and the southern limit of the western Canadian boreal forest. Can. J. For. Res. 24: 1835-1845.

Kabzems, A., A.L. Kosowan and W.C. Harris. 1976. Mixedwood section in an ecological perspective: Saskatchewan. Tech. Bull. No. 8. Dept. Tourism and Renewable Resources, Forestry Branch. $118 \mathrm{p}$.

Kershaw, K.A. 1977. Studies on lichen-dominated systems. An examination of some aspects of the northern boreal lichen woodlands in Canada. Can. J. Bot. 55: 393-410.

Kielland, K. 1994. Amino acid absorption by arctic plants: implications for plant nutrition and nitrogen cycling. Ecology 75: 2373-2383.

La Roi, G.H. 1967. Ecological studies in the boreal spruce-fir forests of the North American taiga. Ecol. Monogr. 37: 229-253.

La Roi, G.H. and M.H.L. Stringer. 1976. Ecological studies in the boreal spruce-fir forests of the North American taiga. II. Analysis of the bryophyte flora. Can. J. Bot. 54: 619-643.

Larsen, J.A. 1980. The boreal ecosystem. Academic Press, New York. $500 \mathrm{p}$.

Larsen, J.A. 1982. Ecology of the northern lowland bogs and conifer forests. Academic Press, New York. 307 p.

Meidinger, D.V. and J. Pojar. 1991. Ecosystems of British Columbia. Special Rep. Ser. No. 6. Research Branch, British Columbia Min. Forests, Victoria, BC. 330 p.

Moss, E.H. 1952. Grassland of the Peace River region, western Canada. 
Can. J. Bot. 30: 98-124.

Murray, D.F. 1987. Breeding systems in the vascular flora of arctic North America. Pp. 239-262 In: K.M. Urbanska, ed. Differentiation patterns in higher plants. Academic Press, London.

Oswald, E.T. and J.P. Senyk. 1977. Ecoregions of Yukon Territory. Environment Canada, Canadian Forestry Service. Victoria, BC. $115 \mathrm{p}$.

Péwé, T.L. 1975. Quaternary geology of Alaska. U. S. Geol. Surv. Prof. Pap. 835. Washington, DC.

Pojar, J. 1983. Boreal and subalpine grasslands of northern British Columbia. Pp. 249-261 In: A.C. Nicholson, A. McLean and T.E. Baker, eds. Grassland ecology and classification, Symp. Proc. British Columbia Mininstry of Forests, Victoria, BC.

Pojar, J., K. Klinka and D.V. Meidinger. 1987. Biogeoclimatic ecosystem classification in British Columbia. For. Ecol. Manage. 22: 119-154.

Raup, H.M. 1934. Phytogeographic studies in the Peace and upper Liard River regions, Canada. Contrib. Arnold Arboretum VI: 1-230. Read, D.J. 1991. Mycorrhizas in ecosystems. Experientia 47: 376-391.

Rowe, J.S. 1961. A critique of some vegetational concepts as applied to forests of northwestern Alberta. Can. J. Bot. 39: 1007-1017. Rowe, J.S. 1972. Forest regions of Canada. Publ. 1300. Dept. Environm., Can. Forestry Service. Ottawa, ON. 172 p.

Rowe, J.S. 1992. Prologue. For. Chron. 68: 22-24.

Rowe, J.S. and G.W. Scotter. 1973. Fire in the boreal forest. Quat. Res. 3: 444-464.

Shaw, C.H., H. Lundkvist, A. Moldenke and J.R. Boyle. 1991. The relationships of soil fauna to long-term forest productivity in temperate and boreal ecosystems: processes and research strategies. Pp. 39-77 In: W.J. Dyck and C.A. Mees, eds. Long-term field trials to assess environmental impacts of harvesting. Proceedings, IAE/BE T6/A6 Workshop, Florida, USA, Feb. 1990. IEA/BE T6/A6 Rep. No. 5. For. Res. Inst. Bull. No. 161, Rotorua, N.Z.

Sims, R.A., W.D. Towill, K.A. Baldwin and G.M. Wickware. 1989. Field guide to the forest ecosystem classification for northwestern Ontario. Ont. Min. Nat. Resources, Toronto, ON. 191 p.
Stanek, W. and L. Orloci. 1987. Some silvicultural ecosystems in the Yukon. Inform. Rep. BC-X-293. Can. For. Serv., Victoria, BC. $56 \mathrm{p}$.

Strong, D.R. and K.R. Leggat. 1981. Ecoregions of Alberta. ENR Tech. Rep. No. T/4. Alberta Energy and Natural Resources. Edmonton, AB. 64 p.

Timoney, K.P., G.H. La Roi, S.C. Zoltai and A.L. Robinson. 1993. Vegetation communities and plant distributions and their relationships with parent materials in the forest-tundra of northwestern Canada. Ecography 16: 174-188.

Van Cleve, K., C.T. Dyrness, L.A. Viereck, J. Fox, F.S. Chapin III and W. Oechel. 1983. Taiga ecosystems in interior Alaska. BioScience 33: 39-44.

Van Cleve, K., F.S. Chapin III, P.W. Flanagan, L.A. Viereck and C.T. Dyrness. 1986. Forest ecosystems in the Alaskan taiga. Springer-Verlag, New York. 230 p.

Van Cleve, K., F.S. Chapin III, C.T. Dyrness, and L.A. Viereck. 1991. Element cycling in taiga forests: state-factor control. BioScience 41: 78-88.

Viereck, L.A. 1971. Alaska vegetation types. Map@1:5,000,000. Compiled for L.A. Viereck and E.L. Little. 1972. Alaska trees and shrubs. U.S.D.A. Agric. Handb. 410. 265 p.

Viereck, L.A., C.T. Dyrness, A.R. Batten and K.J. Wenzlick. 1992. The Alaska vegetation classification. Gen. Tech Rep. PNW-GTR286. U.S.D.A. For. Serv., Pac. Northwest Res. Sta. Portland, OR. 278 p.

Wahrhaftig, C. 1965. Physiographic divisions of Alaska. U.S. Geol. Surv. Prof. Pap. 482. Washington, DC. 52 p.

Zasada, J.C. and E.C. Packee. 1994. The Alaska region. Pp. xxx In Regional silviculture of the United States. Wiley-Interscience (in press).

Zoltai, S.C., S. Taylor, J.K. Jeglum, G.F. Mills and J.D. Johnson. 1988. Wetlands of boreal Canada. Pp 97-154 In: National Wetlands Working Group. Wetlands of Canada. Ecol. Land Class. Ser. No. 24. Environm. Canada, Ottawa, Ont. and Polyscience Publications Inc., Montreal, PQ 